\title{
Oversimplification of complex harvest modeling issues outlined in Welch et al. (2014)
}

\author{
T Mark Willette ${ }^{1 *}$, Pat Shields ${ }^{1}$ and Eric C Volk ${ }^{2}$
}

\begin{abstract}
In their paper, 'Migration behavior of maturing sockeye (Oncorhynchus nerka) and Chinook salmon (O. tshawytscha) in Cook Inlet, Alaska, and implications for management,' Welch et al. (Anim. Biotelem. 2:18, 2014) report data on migratory behavior and relative swimming depths of Chinook and sockeye salmon near the Eastside Setnet (ESSN) fishery, Cook Inlet, Alaska, using acoustically tagged fish and an anchored array of acoustic receivers. Using this information, they provide a model to estimate changes in Chinook and sockeye salmon harvests associated with potential regulatory changes affecting surface gillnet depths in this fishery. We are concerned that the modeling exercise paints an unrealistic picture of how simply changing gillnet dimensions would translate into a viable management approach to preserve or increase sockeye salmon harvests while minimizing catch of Chinook salmon. Much of this fishery occurs in very shallow water, and Cook Inlet tides range about $10 \mathrm{~m}$ with tidal current speeds reaching about $9 \mathrm{~km} \mathrm{hr}^{-1}$. Model assumptions that gillnets in this dynamic environment were hanging vertically and that gillnets did not reach the bottom are not valid. Gillnets in this fishery billow in strong currents causing the lead lines at the bottom of the nets to rise in the water column, and an unknown but high fraction of all gillnets reach the bottom for some portion of each tide cycle. We believe further information and a more sophisticated analysis is needed to realistically model changes in Chinook and sockeye salmon harvests in relation to gillnet depths, and we are concerned about unintended consequences that may arise from unrealistic solutions based on limited data proposed in the regulatory arena.
\end{abstract}

Keywords: Chinook salmon, Oncorhynchus tshawytscha, Sockeye salmon, Oncorhynchus nerka, Acoustic telemetry, Migratory behavior, Swimming depth, Gillnet fishery, Harvest modeling, Fishery management

\section{Background}

In their paper, 'Migration behavior of maturing sockeye (Oncorhynchus nerka) and Chinook salmon (O. tshawytscha) in Cook Inlet, Alaska, and implications for management,' Welch et al. [1] provide interesting insights on migratory behavior and relative swimming depths of Chinook and sockeye salmon near the Eastside Setnet (ESSN) fishery, Cook Inlet, Alaska, using acoustically tagged fish and an anchored array of acoustic receivers. Based on data from 11 Chinook and 25 sockeye salmon, a central finding of their paper is that Chinook were deeper swimmers than sockeye salmon in the study area, with median migration depths of 4.8 and $1.8 \mathrm{~m}$, respectively. Conceptually, these differences in water column distributions offer a means to

\footnotetext{
* Correspondence: mark.willette@alaska.gov

'Alaska Department of Fish and Game, 43961 Kalifornsky Beach Rd. Suite B, Soldotna, Alaska 99669, USA

Full list of author information is available at the end of the article
}

selectively avoid the deeper migrating species in set gillnet fisheries by using shallower nets. The authors provide a modeling exercise ([1], Figure nine) which uses this data to predict how changes in gillnet dimensions could preserve desired harvest of migrating sockeye salmon while avoiding deeper swimming Chinook salmon, a species of particular concern returning to the Kenai River. Unfortunately, limited data from very few fish and a number of caveats, some noted by the authors, make their approach unrealistically simple and potentially misleading in the highly contentious regulatory environment of Cook Inlet fisheries.

\section{Main text \\ The ESSN fishery is conducted in a $90-\mathrm{km}$ section along the eastern shore of Cook Inlet extending from the beach to approximately $2.4 \mathrm{~km}$ offshore [2]. The bottom slope is very shallow with extensive mud flats at low}


tide. South of the Kenai River, water depths at mean lower low water (MLLW) average about $10 \mathrm{~m}$ along the offshore boundary of the fishery (http://www.ngdc.noaa. gov). North of the Kenai River, in the Salamatof statistical area, where many Chinook salmon are caught, water depths near the offshore boundary at MLLW average about $15 \mathrm{~m}$. Nets are often fishing in much shallower water towards shore. Spring tides in Cook Inlet range about $10 \mathrm{~m}$ and tidal current speeds can reach about $9 \mathrm{~km} \mathrm{hr}^{-1}[3,4]$. The tide stage at one end of the district is out of phase with the tide stage at the opposite end of the district by about $60^{\circ}$ (http://tidesandcurrents. noaa.gov). The marine array of acoustic receivers used by Welch et al. [1] consisted of 16 acoustic receivers located along the offshore boundary of the ESSN fishery (approximately $2.4 \mathrm{~km}$ from shore) and 54 acoustic receivers located along transects extending $15 \mathrm{~km}$ offshore of the seaward boundary of the ESSN fishery. Thus, migration depth data were generally collected in water much deeper than where the fishery actually occurs.

A fundamental assumption used by Welch et al. in calculating the potential harvests of Chinook and sockeye salmon based on swimming depth data is that gillnets hang straight down, with a standard 45 mesh net covering about $5.5 \mathrm{~m}$ in depth. While we understand that this assumption was adopted for simplicity, the actual fishing depths of nets in this fishery are undoubtedly far more dynamic. In reality, gillnets in this fishery billow like a sail in strong currents causing the lead lines at the bottom of the nets to rise in the water column. The authors acknowledge that deep nets may rise off the bottom more than shallow nets due to their greater surface area and, thus, resistance in the strong current, potentially reducing some of the assumed difference in net depths. But, there are other variables that can affect the effective fishing depth of gillnets including current speed, which changes during the tide cycle; the weight of the lead line; and the number of fish caught in the net at any given time, which increases drag but also adds weight to the net. Effective fishing depth of individual gillnets changes through a tide cycle, and because tides are out of phase in different parts of the fishing district, effective fishing depths of nets at various locations in the district can be very different at any given time. It is likely that actual harvests of either species would differ substantially from those predicted under the simple scenario advanced in this study.

A second concern is the implicit assumption in the authors' analysis that gillnets would not rest on the sea bottom, allowing fish to swim below the nets. They point out that sport fishers frequently troll for Chinook salmon in very shallow water in this area. Since water depth in much of the ESSN fishery is very shallow, particularly south of the Kenai River, it is clear that a high fraction of all gillnets reach the bottom for some portion of each tide cycle during the fishery. Fishermen may also move their nets through the tide cycle depending upon conditions. Without a better understanding of net locations with respect to the sea floor through a tide cycle, it is very difficult to predict actual harvest changes with altered net depth. In addition, differences in depth distributions of Chinook and sockeye salmon in deep water will not be maintained in shallow water where the bottom forces their distributions to overlap, and shallower nets will not affect harvests of Chinook relative to sockeye salmon when nets reach the sea floor.

In an earlier study focused on how to minimize harvests of Chinook salmon in the ESSN fishery, Bethe and Hansen [5] found that the highest average harvest rate of Chinook salmon (0.41 per net set) occurred in set nets located at intermediate distances from shore where gillnets were likely reaching the bottom at low tide. The average harvest rate of Chinook salmon further inshore ( 0.23 per net set) and offshore ( 0.15 per net set) was lower. Bethe and Hansen's [5] data are consistent with the notion that Chinook salmon are most often captured as they migrate inshore and first encounter gillnets that reach the bottom. Reducing the depth of gillnets may simply shift the harvest closer to the beach where nets again reach the bottom. Importantly, this study [5] also found that the vertical distribution of Chinook salmon catches in gill nets was essentially uniform at all distances from shore.

Finally, size distributions of acoustically tracked Chinook salmon and those captured in the ESSN fishery were very different. The smallest acoustically tracked Chinook salmon was about $85 \mathrm{~cm}$ in length [6], whereas $82 \%$ of Chinook salmon captured in the ESSN fishery were $<85 \mathrm{~cm}$ (mode $50 \mathrm{~cm}$ ) in length [7]. Welch et al. [6] found that Chinook salmon mean swimming depths were not correlated with length, but this may have been due to the limited sample size and data range. Folkedal et al. [8] found that smaller Atlantic salmon swam at shallower depths in commercial sea cages.

\section{Conclusions}

In our view, analyses in Welch et al. [1] oversimplify problems associated with estimating changes in Chinook and sockeye salmon harvests that may occur with changing gillnet depths, and actual harvest changes would likely differ substantially. We do not take issue with the central findings of the study which document migratory behavior of these species within the study area where the acoustic array was located. Unfortunately, despite best efforts, this study tagged very few Chinook salmon and not all of those were Kenai River origin fish. We do not know how well these fish represent Kenai River Chinook salmon behavior in general or how their migration depths 
may change as they leave the study area for the river and shallower water. Combined with the complexities of net and fishermen behavior as the fishery is prosecuted, predicting actual harvest impacts to Chinook and sockeye salmon from simple changes in net dimensions is very difficult and uncertain. We are concerned that this harvest modeling exercise paints an unrealistic picture of how simply changing gillnet dimensions would translate into a viable management approach to preserve or increase sockeye salmon harvests while minimizing Chinook salmon harvests.

The complexity of the problem may require simulating gillnet behavior in tidal currents and the migratory behavior of Chinook and sockeye salmon in the ESSN fishery. Modeling gillnet behavior will require information on locations of all gillnets and bottom depth at each net location. The effective fishing depths of gillnets should also be determined over a range of current speeds with nets that are hung with various amounts of web and lead line. Use of time-depth recorders on various parts of the net could be used to refine our understanding of net behavior. These data could be used in conjunction with a tide model to simulate the behavior of gillnets during the course of a fishing season. Simulating Chinook and sockeye salmon migratory behavior will require information on swimming depths of Chinook and sockeye salmon in shallower waters and a thorough understanding of how these fish migrate within the fishery. Developing the level of understanding of these processes necessary to accurately estimate harvest changes will be very costly and challenging. We are committed to providing the best information possible to the Alaska Board of Fisheries as they deliberate regulatory changes. However, we are also acutely aware of unintended consequences that may arise from unrealistic solutions based on limited data proposed in the regulatory arena.

\section{Abbreviations}

ESSN: Eastside Setnet; MLLW: Mean lower low water.

\section{Competing interests}

The authors declare that they have no competing interests.

\section{Authors' contributions}

TMW, PS, and ECV co-wrote the manuscript. All authors read and approved the final manuscript.

\footnotetext{
Authors' information

TMW has been employed by the State of Alaska Department of Fish and Game (ADF\&G) for 23 years and currently holds the position of Research Project Leader for the ADF\&G, Commercial Fisheries Division in upper Cook Inlet. He has been in this position for the past 14 years.

PS has been employed by the ADF\&G for 30 years and currently holds the position of Area Management Biologist for the ADF\&G, Commercial Fisheries Division in upper Cook Inlet. He has held this position for the past 4 years and previously held the position of Assistant Area Management Biologist for 10 years.

ECV has been employed by the ADF\&G for 10 years and currently holds the position of Chief Fishery Scientist for salmon, Commercial Fisheries Division, Headquarters.
}

\section{Acknowledgements}

The preparation and submission of this manuscript was funded by the State of Alaska.

\section{Author details}

'Alaska Department of Fish and Game, 43961 Kalifornsky Beach Rd. Suite B, Soldotna, Alaska 99669, USA. ${ }^{2}$ Alaska Department of Fish and Game, 333 Raspberry Rd, Anchorage, Alaska 99518, USA.

Received: 3 February 2015 Accepted: 11 March 2015

Published online: 26 March 2015

\section{References}

1. Welch DW, Porter AD, Winchell P. Migration behavior of maturing sockeye (Oncorhynchus nerka) and Chinook salmon (O. tshawytscha) in Cook Inlet, Alaska, and implications for management. Anim Biotelem. 2014;2:18.

2. Shields $P$, Dupuis A. Upper Cook Inlet commercial fisheries annual management report, 2013. Fishery Management Report 13-49. Anchorage, AK: Alaska Department of Fish and Game; 2013. Available at: http://www.adfg.alaska.gov/FedAidpdfs/FMR13-49.pdf.

3. Muench RD, Schumacher JD, Pearson CA. Circulation in the lower Cook Inlet, Alaska. NOAA Tech Mem. 1981;28:PB82-126418. ERL PMEL.

4. Moore SE, Shelden KEW, Litzky LK, Mahoney BA, Rugh DJ. Beluga, Delphinapterus leucas, habitat associations in Cook Inlet. Alaska Mar Fish Rev. 2000;62(3):60-80.

5. Bethe, ML, Hansen, P. Investigations of methods and means to minimize Chinook salmon harvest in the East Side Set Net Fishery of Upper Cook Inlet, 1996. Special Publication 98-3. Anchorage, AK: Alaska Department of Fish and Game; 1998. Available at: http://www.adfg.alaska.gov/FedAidPDFs/ sp98-03.pdf.

6. Welch DW, Porter AD, Winchell P. Chinook and sockeye salmon migration patterns in Cook Inlet, 2013. Report to the State of Alaska: Department of Fish and Game, Division of Commercial Fisheries, By Kintama Research Services, Ltd.; 2013.

7. Eskelin, T, Barclay, AW, Antonovich, A Mixed stock analysis and age, sex, and length composition of Chinook salmon in the EastSide Set Gillnet Fishery in upper Cook Inlet, Alaska, 2010-2013. Fishery Data Series 13-63. Anchorage, AK: Alaska Department of Fish and Game; 2013. Available at: http://www.adfg.alaska.gov/FedAidPDFs/FDS13-63.pdf.

8. Folkedal O, Stien LH, Nilsson J, Torgersen T, Fosseidengen JE, Oppedal F. Sea caged Atlantic salmon display size-dependent swimming depth. Aquatic Living Res. 2012;25(2):143.

\section{Submit your next manuscript to BioMed Central and take full advantage of:}

- Convenient online submission

- Thorough peer review

- No space constraints or color figure charges

- Immediate publication on acceptance

- Inclusion in PubMed, CAS, Scopus and Google Scholar

- Research which is freely available for redistribution 